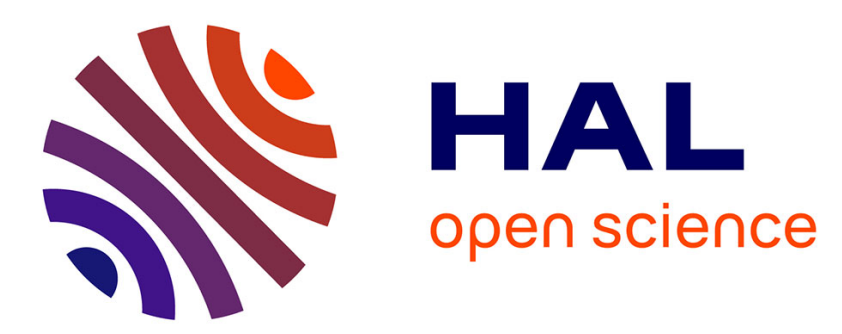

\title{
Solvent effects on the stability of nifuroxazide complexes with cobalt(II), nickel(II) and copper(II) in alcohols.
}

\author{
Mustayeen A Khan, S Kauser Ali, Gilles M Bouet
}

\section{To cite this version:}

Mustayeen A Khan, S Kauser Ali, Gilles M Bouet. Solvent effects on the stability of nifuroxazide complexes with cobalt(II), nickel(II) and copper(II) in alcohols.. Journal of Inorganic Biochemistry, 2002, 90 (1-2), pp.67-70. 10.1016/S0162-0134(02)00371-9 . hal-03218039

\section{HAL Id: hal-03218039 \\ https://univ-angers.hal.science/hal-03218039}

Submitted on 6 May 2021

HAL is a multi-disciplinary open access archive for the deposit and dissemination of scientific research documents, whether they are published or not. The documents may come from teaching and research institutions in France or abroad, or from public or private research centers.
L'archive ouverte pluridisciplinaire HAL, est destinée au dépôt et à la diffusion de documents scientifiques de niveau recherche, publiés ou non, émanant des établissements d'enseignement et de recherche français ou étrangers, des laboratoires publics ou privés. 


\title{
Solvent effects on the stability of nifuroxazide complexes with cobalt(II), nickel(II) and copper(II) in alcohols
}

\author{
Mustayeen A. Khan ${ }^{\mathrm{a}, *}$, S. Kauser Ali ${ }^{\mathrm{b}}$, Gilles M. Bouet ${ }^{\mathrm{a}}$ \\ ${ }^{\mathrm{a}}$ Laboratoire de chimie de coordination, Faculté de Pharmacie, Universite d'Angers, 16 Boulevard Daviers, F-49100 Angers, France \\ ${ }^{\mathrm{b}}$ Polymer Division, PCSIR Laboratories, Karachi 75280, Pakistan
}

Received 16 July 2001; received in revised form 9 January 2002; accepted 10 January 2002

\begin{abstract}
A spectrophotometric study of the complexation of nifuroxazide with cobalt(II), nickel(II) and copper(II) was carried out in different alcohols. The formation of a complex in each case is reported and their stability constants have been calculated. For a given solvent, the stability of the complexes increases from cobalt to copper. In the case of copper(II), the stability varies as an inverse function of the dielectric constant of the solvent. A possible structure of the complex is proposed. (C) 2002 Elsevier Science Inc. All rights reserved.
\end{abstract}

Keywords: Nifuroxazide; Metal complexes; Stability; Alcohols

Nifuroxazide is the common name of 5-nitro 4-furfurylidene benzhydrazide or 4-hydroxybenzoic [(5-nitro 2-furanyl) methylene] hydrazide acid [1]. It is therefore a nitro furanic compound with the nitro group at position 5 on the heterocycle (Fig. 1) and its crystal and molecular structure was described by Pniewska [2].

Nifuroxazide or Ambatrol is an important pharmaceutical. This compound has known antibacterial properties [3-5] and is extensively used as an intestinal antiseptic in treatment of infectious diarrhea, useful against Escherichia coli, Salmonella paratyphi, Streptococcus faecalis and Shigella dydenteriae. It was demonstrated that the pharmacological activity is mainly due to its configuration and is greatly diminished if the nitro group is shifted from position 5 to either position 4 or 3 [6]. Dual functionalized nitrofurans may be cytotoxic towards hypoxic cells [7] but

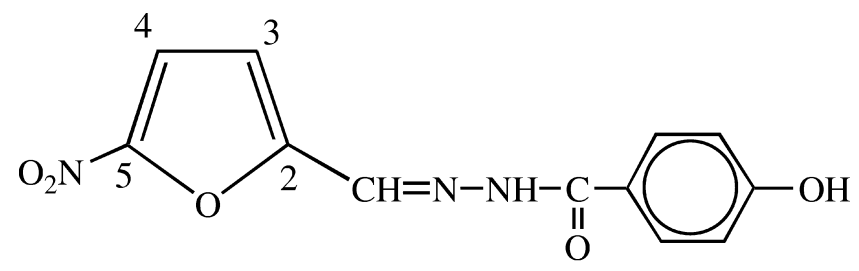

Fig. 1. Chemical structure of nifuroxazide.

\footnotetext{
*Corresponding author. Tel.: +33-2-4122-6600; fax: +33-2-41486733.

E-mail address: mustayeen.khan@univ-angers.fr (M.A. Khan).
}

Cohen et al. [8] showed that 5-nitrofurans and 5-nitrothiophenes are carcinogenic substances. The titration of nifuroxazide has been performed by cyclic voltammetry in water [9].

Our laboratory has taken up the study of complexation of various furan derivatives with some transition metals in order to determine the physicochemical properties of these complexes and in some cases physiological experiments were also conducted and these results have already been reported [10-17].

In this study, cobalt, nickel and copper in their divalent states were complexed with nifuroxazide. Cobalt and nickel were chosen for their importance in biological and physiological activities-cobalt is after all, the central metal ion in the vitamin B complex. Copper, on the other hand, is toxic but has been studied because of the ease with which it complexes with different ligands. Moreover, among $\mathrm{Co}, \mathrm{Ni}$, and $\mathrm{Cu}$, copper is the most important trace-element in the human body for physiological activity. Its amount in organism is 70 times that of $\mathrm{Ni}$, and $\mathrm{Co}$; its toxic dose is approximately the same as for $\mathrm{Co}$; and $\mathrm{Ni}$ is an allergen. The complexation was carried out in methanol, ethanol and propan-2-ol. The solutions of metal complexes are usually not stable in air and thus, spectra of all solutions were recorded immediately after their preparation. The apparent overall stability constants, $\beta_{j}$, were calculated for the equilibrium:

$$
\mathrm{M}^{2+}+\mathrm{L} \rightleftharpoons[\mathrm{ML}]^{2+}
$$


$\beta_{j}=\frac{\left[\mathrm{ML}^{2+}\right]}{\left[\mathrm{M}^{2+}\right][\mathrm{L}]}$

with $\mathrm{M}=\mathrm{Co}$, $\mathrm{Ni}$ or $\mathrm{Cu} ; \mathrm{L}=$ nifuroxazide.

Methanol, ethanol and propan-2-ol (p.a. Merck, 99\% minimum) were used without further treatment. Nifuroxazide was kindly provided by Synthelabo France or purchased from Sigma. Stock solutions were prepared for cobalt and nickel with their hexahydrated chloride salts, and for copper from hexahydrated perchlorate (all Fluka), by dissolving calculated quantities in the respective solvents. The hexahydrated salts were used to maintain the same experimental conditions as in other earlier studies. Nifuroxazide is insoluble in water but is slightly soluble in alcohols, so nearly saturated solutions were used. All the solutions were standardized gravimetrically. The absorption spectra were recorded with a Lambda 19 Perkin-Elmer spectrophotometer at $25.0 \pm 0.2^{\circ} \mathrm{C}$. The ionic strength of the solutions was kept constant at $0.01 \mathrm{M}$ using a solution of the supporting electrolyte, sodium perchlorate (Fluka).

Nifuroxazide has three main bands of absorption at 209, 287 and $367 \mathrm{~nm}$ as well as a shoulder band at about 250 $\mathrm{nm}$. For fixed concentrations of metal ions $\left(\left[\mathrm{Co}^{2+}\right]=10^{-3}\right.$, $\left[\mathrm{Ni}^{2+}\right]=10^{-3}$ and $\left.\left[\mathrm{Cu}^{2+}\right]=5 \times 10^{-4} \mathrm{M}\right)$, solutions were prepared with nifuroxazide concentration ranging from zero to $10^{-4} \mathrm{M}$. The absorption spectra of all these solutions were recorded in the UV-Vis region in methanol, ethanol and propanol. Out of these nine experimental variations of absorption, representative spectra of copper(II)-nifuroxazide solutions in propan-2-ol are presented in Fig. 2.

In the absence of nifuroxazide, there is a maximum at $220 \mathrm{~nm}$. The addition of the ligand produces a band between 350 and $450 \mathrm{~nm}$ and with the increase in ligand concentration this band splits into two: one centered at about $370 \mathrm{~nm}$ and a clear shoulder band stabilizing at about $450 \mathrm{~nm}$. This latter band, absent in the spectra of the metal ion or the ligand, clearly indicates the formation of a new species. The same results were obtained with $\mathrm{Co}(\mathrm{II})$ and $\mathrm{Ni}(\mathrm{II})$. The solutions have a slight blue coloration. With copper solutions, when there is a band at about 400 $\mathrm{nm}$, it is reported that copper is in a flattened tetrahedral configuration $\left(\mathrm{D}_{2 \mathrm{~d}}\right.$ symmetry). Demuynck [18], using LCAO-MO-SCF ab initio calculations in a theoretical study of bonding in $\mathrm{CuCl}_{4}^{2-}$, showed that the configuration $T_{d}$ is more stable, ca $72 \mathrm{~kJ} \mathrm{~mol}^{-1}$, than the square planar configuration $\left(\mathrm{D}_{4 \mathrm{~h}}\right.$ symmetry) and that the configuration $\mathrm{D}_{2 \mathrm{~d}}$ is still more stable, by about $8 \mathrm{~kJ} \mathrm{~mol}^{-1}$. The difference in energy calculated between these three configurations is, however, sufficiently low and solvent effects

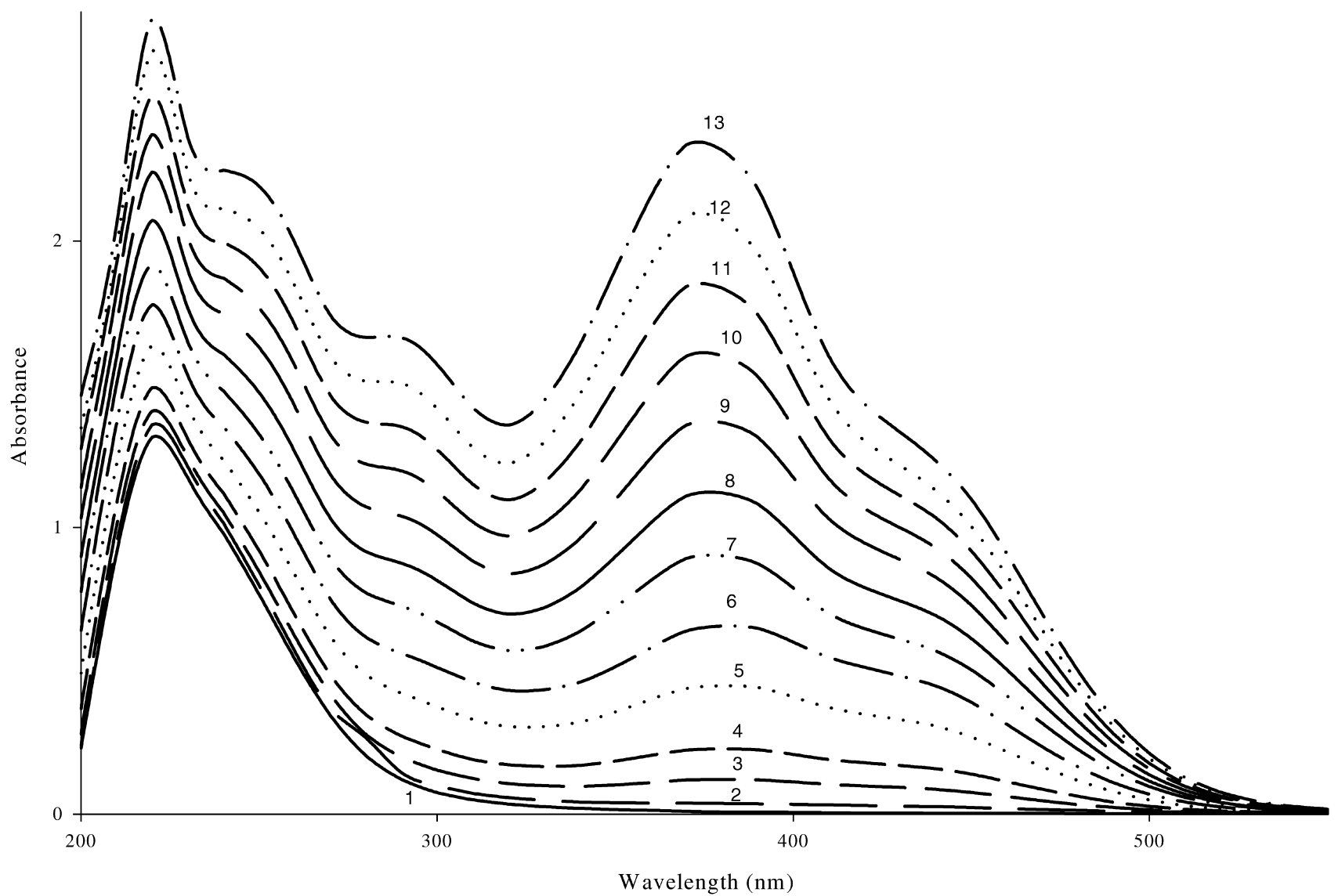

Fig. 2. Experimental spectra of copper(II) $\left(5 \times 10^{-4} \mathrm{M}\right)$ and nifuroxazide solutions in propan-2-ol $(\mathrm{C}$ in $\mathrm{M}): 1: \mathrm{C}=0 ; 2: \mathrm{C}=10^{-6} ; 3: 5 \times 10^{-6} ; 4: 10^{-5} ; 5$ : $2 \times 10^{-5} ; 6: 3 \times 10^{-} ; 7: 4 \times 10^{-5} ; 8: 5 \times 10^{-5} ; 9: 6 \times 10^{-5} ; 10: 7 \times 10^{-5} ; 11: 8 \times 10^{-5} ; 12: 9 \times 10^{-5} ; 13: 10^{-4}$. 
can alter the geometry. In a recent study concerning the coordination geometry of the copper atoms of thiosemicarbazones, Jouad has argued that the calculated bond angles favor a structure of the complex somewhere between that of tetrahedral and square planar configuration [19]. So our proposition of a square planar structure in solution is still quite possible despite a band near $400 \mathrm{~nm}$.

The calculation of the stability constants is based on the computer program SIRKO which was conceived for the calculation of such parameters from spectrophotometric experimental data [20]. It is based on a least-squares method and its essential details were given in our earlier publications [16,21]. The calculated results for these stability constants with the three metals in the three solvents are grouped in Table 1.

This table shows that stability increases at first slowly from cobalt to nickel and then steeply from nickel to copper. There is no single factor that can explain satisfactorily the stability of the complexes. The ratio of charge to radius is considered to be of prime importance. Other possible factors are decreasing ionic radii and the increasing ionic potentials. However, all these factors are interlinked and they favor the cupric ion with which the stability is nearly always the highest in comparison to other $3 \mathrm{~d}$ transition metals. This was reported earlier for similar systems [22] and is in conformity with the IrvingWilliams order of stabilities [23].

For a given metal, logically the stability increases from methanol to propanol, but this is observed in the case of copper only. For cobalt and nickel the deviation from this pattern is difficult to explain outright, nonetheless, the low values of the formation constants with these metals may play a significant role.

Eventually, the stability of the complexes is the interesting parameter under study here and this is lower in methanol than in propanol, following the accepted norm that the higher the solvating power of the solvent, the lower the stability of complexes. This is also the main reason for higher stability in methanol when compared with water where hydrogen bonding is prevalent [24].

This work does not permit us to elucidate with precision the structure of the complex formed in solution especially as no crystal structure studies were performed because we were not able to obtain monocrystals. However, we reported earlier that in the case of $\left[\mathrm{CuCl}_{2}(\mathrm{FPSC})\right]$, where FPSC is 2-furfural 4-phenylsemicarbazone (Fig. 3), coordi-

Table 1

Stability constants for the metal-nifuroxazide complexes in the three alcohols

\begin{tabular}{|c|c|c|c|}
\hline \multirow[t]{2}{*}{ Metal } & \multicolumn{3}{|l|}{ Solvent $\left(\varepsilon_{\mathrm{R}}\right)$} \\
\hline & $\mathrm{MeOH}(32.6)$ & EtOH (24.3) & $\mathrm{PrOH}(18.3)$ \\
\hline$\overline{\mathrm{Co}^{2+}}$ & $17 \pm 2$ & Unstable & $24 \pm 2$ \\
\hline $\mathrm{Ni}^{2+}$ & $41 \pm 4$ & $11 \pm 1$ & $33 \pm 3$ \\
\hline $\mathrm{Cu}^{2+}$ & $695 \pm 55$ & $3340 \pm 260$ & $4060 \pm 320$ \\
\hline
\end{tabular}

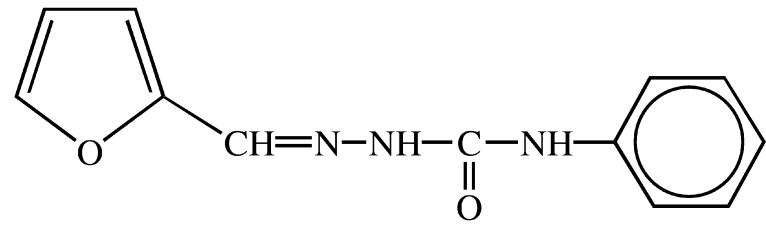

Fig. 3. Chemical structure of 2-furfural 4-phenyl semicarbazone (FPSC).

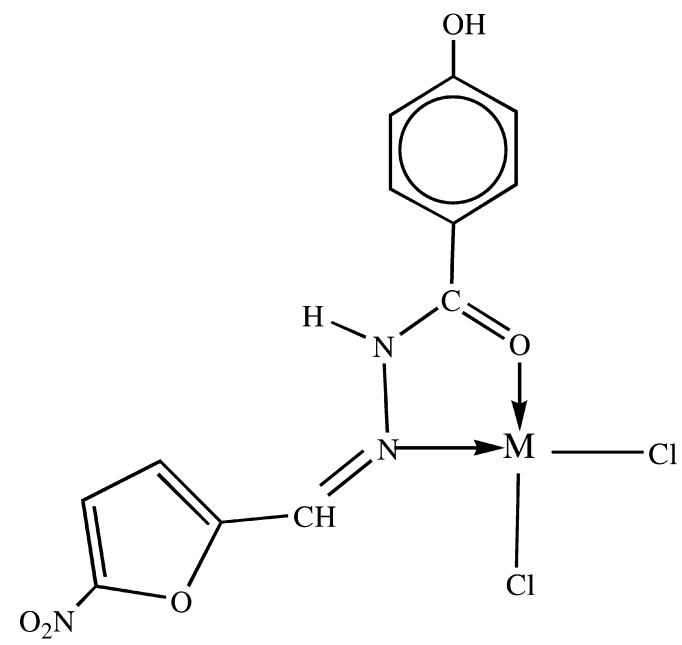

Fig. 4. Proposed structure for the metal-nifuroxazide complex in solution.

nation occurs through the $\mathrm{O}$ carbonyl and the $\mathrm{N}$ imine atoms leading to a square planar structure [25]. Considering that the structure of FPSC resembles that of nifuroxazide, we propose, by analogy, that in this case too, the same coordinating atoms are involved for the three metals in each solvent. This proposed configuration presented in Fig. 4, supported by the aforementioned analogy in the solid state, remains to be confirmed.

\section{References}

[1] The Merck Index, 9th Edition, 1971, Merck, USA.

[2] B. Pniewska, M. Januchowski, Pol. J. Chem. 72 (12) (1998) 2629.

[3] A. Thabaut, J.L. Durosoir, Gazette Méd. France 85 (1978) 4516.

[4] R. Vanhoof, H. Coignau, G. Stas, J.P. Butzler, Acta Clin. Belg. 36 (3) (1981) 126.

[5] F. Léonard, A. Andrémont, C. Tancrède, J. Appl. Bacteriol. 58 (6) (1985) 545 .

[6] M. Carron, A. Julien, T. Julia, C. Garzynska, Ann. Pharm. Fr. 21 (1963) 287.

[7] D.W. Sieman, Int. J. Radiat. Oncol. Biol. Phys. 22 (4) (1992) 697.

[8] S.M. Cohen, E. Erturk, G.T. Bryan, J. Natl. Cancer Inst. 57 (2) (1996) 277.

[9] A. Radi, M.A. El-Ries, Anal. Sci. 15 (4) (1999) 385.

[10] G. Bouet, G. Ibrahim, M.A. Khan, Transition Met. Chem. 21 (6) (1996) 530.

[11] G. Ibrahim, M.A. Khan, P. Richomme, O. Benali-Baitich, G. Bouet, Polyhedron 16 (19) (1997) 3455.

[12] I.H. Hall, K. Taylor, M.C. Miller, X. Do Thanh, M.A. Khan, G. Bouet, Anticancer Res. 17 (4A) (1997) 2411. 
[13] I.H. Hall, C. Lee, G. Ibrahim, M.A. Khan, G. Bouet, Appl. Organomet. Chem. 11 (1997) 565.

[14] B. Jamali, G. Ibrahim, G. Bouet, M.A. Khan, P. Allain, X. Do Thanh, Biol. Rhythm Res. 29 (3) (1998) 229.

[15] G. Ibrahim, M.A. Khan, E. Chebli, G. Bouet, Transition Met. Chem. 24 (3) (1999) 294.

[16] G. Ibrahim, G. Bouet, I.H. Hall, M.A. Khan, J. Inorg. Biochem. 81 (1-2) (2000) 29

[17] I.H. Hall, C.B. Lackey, T.D. Kistler, R.W. Durham Jr., E.M. Jouad, M. Khan, X. Do Thanh, S. Djebbar-Sid, O. Benali-Baitich, G.M. Bouet, Pharmazie 55 (2000) 937.

[18] J. Demuynck, A. Veillard, U. Wahlgren, J. Am. Chem. Soc. 95 (1973) 5563.
[19] E.M. Jouad, A. Riou, M. Allain, M.A. Khan, G.M. Bouet, Polyhedron 20 (2001) 67.

[20] V.I. Vetrogon, N.G. Lukyanenko, M.J. Schwing-Weill, F. ArnaudNeu, Talanta 41 (1994) 2105.

[21] M. Khan, G. Bouet, R. Tanveer, R. Ahmed, J. Inorg. Biochem. 75 (2) (1999) 79.

[22] M.A. Khan, G. Bouet, F. Vierling, J. Meullemeestre, M.J. Schwing, Transition Met. Chem. 21 (1996) 213.

[23] H. Irving, R.J.P. Williams, J. Chem. Soc. (1953) 3192.

[24] M.A. Khan, J. Meullemeestre, M.J. Schwing, F. Vierling, Inorg. Chem. 28 (1989) 3306.

[25] G. Ibrahim, M.A. Khan, G. Bouet, Transition Met. Chem. 27 (2002) 34. 